\title{
EUNUCHS IN THE BIBLE
}

\begin{abstract}
In the original texts of the Bible a "eunuch" is termed saris (Hebrew, Old Testament) or eunouchos (Greek, New Testament). However, both these words could apart from meaning a castrate, also refer to an official or a commander. This study therefore examines the 38 original biblical references to saris and the two references to eunouchos in order to determine their meaning in context. In addition two concepts related to eunuchdom, namely congenital eunuchs and those who voluntarily renounce marriage (celibates), are also discussed.
\end{abstract}

\section{INTRODUCTION}

The concept of a "eunuch" (a castrate) is described in the Bible primarily by two words, namely saris (Hebrew, Old Testament) and eunouchos (Greek, New Testament) (Hug 1918:449-455; Horstmanshoff 2000: 101-114). In addition to "eunuch", however, both words can also mean "official" or "commander", while castration is sometimes indirectly referred to without using these terms. This study therefore set out to determine the true appearance of eunuchism in the Bible.

The aim was to use textual context and, in particular, any circumstantial evidence to determine which of the two meanings is applicable in each case where the word saris (O.T.) or eunouchos (N.T.) occurs in the Bible. All instances of the words saris and eunouchos were thus identified in the original Hebrew and Greek texts of the Bible and compared with the later Septuagint and Vulgate texts, as well as with Afrikaans and English Bible translations. The meanings of the words were determined with due cognisance of textual context, relevant historical customs and attitudes relating to eunuchs (Hug 1918:449-455; Grey 1974:579-85; Horstmanshoff 2000:101-14). However, a complete discussion of the particular socio-cultural role played by eunuchs in antiquity, as provided by the theological studies of Spencer (1993: 155-63), Malina \& Neyrey (1991:97-122) and Levinson (2000:11940) in particular, was beyond the scope of this project. 


\section{DEFINITION AND TERMINOLOGY}

A eunuch is defined as someone (usually a man) whose testes (and sometimes also penis and scrotum) have been destroyed or removed. This leads to sterility, and (depending on the stage of life at which it is done) to various degrees of impotence and loss of libido. Pre-pubertal castration causes a "eunuchoid" build (tall, with broad hips, narrow shoulders and breasts like that of a woman), impotence, absence of libido and secondary sexual characteristics (small genitals, lack of beard and unbroken voice). Castration after puberty does not lead to degeneration of secondary sexual characteristics; the build remains unchanged, and reduction of sexual activity is unpredictable. Although sterile, the castrate may remain potent for a year or longer, and some even retain libido throughout their lives. There is a reduction in aggression, but abnormalities of the psyche usually represent a psychological reaction to forced castration and the accompanying humiliation and rejection by the community, in addition to the effects of hormonal deprivation (Grey 1974:579-85).

The origin of saris (which exists in Accadian, Aramaic and Biblical Hebrew) is uncertain, but it may have arisen from two Assyrian words, sa and resi ("he who is at the head") (Koehler \& Baumgartner 1958: 668). There was originally thus no direct connection with castration (Gray 1970:450; Mandelkern 1975:807), since the word merely indicated a person in a responsible position (Grey 1974:579). The second meaning was added later (Gray 1970:450) and two concepts came into being in Judaism, namely saris hamma (a congenital eunuch) and saris adam (a man-made eunuch) (Jastrow 1950:1027; Sheriffs 1990:356). The concept of a congenital eunuch will be discussed below.

The origin of the Greek word eunouchos is also uncertain. The popular opinion is that it is derived from eunen and echo, and means "protector of the bed" (a harem attendant, in particular) (Hug 1918:449450; Horstmanshoff 2000:101-2), but this is strongly doubted by Grey (1974:579), among others. Grey considers the word to have an ancient Semitic origin, related to the concepts "trained, reliable, experienced". In this case, too, there is thus no direct connection with castration, unlike the Greek words ektomias, spadon and apokopai, which can be directly related to eunuch and castration (Liddell, Scott \& Jones 
1968). Hug (1918:449-50) indicated that eunouchos, like saris, may have a primary meaning of "official". Spadon refers to both congenital and man-made eunuchism (Hug 1918:449-50).

In Leviticus 22:24, the Hebrew word katut (meaning "crushed" or "smashed") is used to describe the castration of animals by destruction of the sexual organs (Koehler \& Baumgartner 1958:462). The word is not used elsewhere in the Bible with reference to human beings or animals, but does occur in the context of the destruction of idols and altars (Deut. 9:21; 2 Chron. 34:7), pots (Isiah 30:14) and grain (Joel 4:10).

Deuteronomy 23:1 strongly censures castration by means of the destruction or excision of the sexual organs, but does not explicitly use the word castrate or eunuch (saris).

\section{TERMS IN THE SEPTUAGINT AND THE VULGATE}

The 38 references to saris in the original Hebrew texts of the Old Testament, identified and discussed below (cf. Mandelkern 1975: 807), were checked in the Septuagint and the Vulgate in order to establish the Greek and Latin translations of the Hebrew word. In most cases (26), the Greek term used was eunouchos and the Latin eunucbus. In two cases the Greek was spadon while the Latin remained eunuchus: Genesis 37:36, referring to Potiphar, and Isaiah 39:7, where the prophet foretells the castration of Jewish youths by the Babylonian conqueror. In the Septuagint version of Jeremiah 38:7 the courtier Ebed-Melek is described by the words "he was in the house of the king". The Vulgate translation Esther 2:3 gives minister instead of eunuchus. The courtier in Daniel 1:3, 7, 8-15 and 18 is called archi-eunouchos in the Septuagint (meaning "chief eunuch") and praepositus eunuchorum (with the same meaning) in the Vulgate. In Daniel 2:48 Daniel is called archon satrapon (head of the royal governors) in the Septuagint and praefectus magistratuum (chief official) in the Vulgate. Jeremiah 34:19, and 39:3, 13 could not be found in the Septuagint, while Daniel 11:18 was missing from both the Septuagint and the Vulgate. 


\section{DISCUSSION OF THE SCRIPTURAL PASSAGES}

The original passages containing the words saris or eunouchos will now be analysed in an attempt to establish the intended meaning of these terms. The 1983 translation of the Afrikaans Bible (NAV) and two English translations, namely the King James translation (KJV Thompson's New Chain Reference Bible, third improved edition, 1957) and the New International Version (NIV — New York International Bible Society, 1978), will provide modern parallels.

\subsection{The Old Testament}

In total, the original texts contained 38 references to saris, one reference to katut in relation to animal castration (Lev. 22:24) and one reference to the practice of human castration (Deut. 23:1). From contextual and circumstantial evidence, these texts were then classified as using the words to indicate a eunuch, or to indicate an official, or inconclusively. The term rabsaris (2 Kings 18:17; Jer. 39:3, 13), meaning chief saris, was noted but will not be discussed.

\subsubsection{Textual context indicating "eunuch"}

- In Deuteronomy 23:1 (Afrikaans translation; 23:2 in the Hebrew), the law forbids the community of the Lord to accept anyone who has undergone destruction or removal of their sexual organs. This clearly refers to eunuchs, although the word saris does not occur in the original texts.

- In the book of Esther, saris is repeatedly used in reference to officials in the palace of Ahasveros. Esther 1:10, 12, 15;2:3, 14; 4:4, 5; 6:14 and 7:8 refer to the court officials concerned with the care of the women. These were probably eunuchs, in keeping with the custom of the time in Persian courts. We read of Hegai being in charge of the harem of the king's wives and Susagaz in charge of the harem of concubines, while Harbona is present at the queen's feast. The NAV refers to all of them as "palace officials"; the KJV calls them "chamberlains" and the NIV terms them "eunuchs". 
- 2 Kings 20:18 and Isaiah 39:7 refer to the prophecy of Isaiah that Juda would be overthrown and its inhabitants taken in exile to Babylon. According to the KJV and the NIV, the sons of the king would be made eunuchs; according to the $N A V$, courtiers. Since it was the custom to castrate slaves and prisoners of war in Mesopotamian countries (where human castration probably originated; Hug 1918:449-50; Grey 1974:580), the former interpretation is probably correct.

- In Isaiah 56:3-5, the eunuch is welcomed into the church community with empathy (in contrast to his unconditional rejection in Deut. 23:1).

\subsubsection{Textual context indicating "courtier"}

- Since Potiphar was married (Gen. 39:7) and may even have had a daughter (Gen. 41:45), is it unlikely that he was a eunuch. Thus Genesis 37:36 and 39:1 probably refer to the office of courtier or captain of the palace guard $(N A V, K J V, N I V)$. There is no reason to assume that Pharaoh's cup-bearer and baker were necessarily eunuchs either (Gen. 40:2, 7).

- The courtiers of the kings of Israel in 2 Kings 8:6, 2 Chronicles 18:8, 1 Kings 22:9 and 1 Chronicles 28:1, the Persian porters in Esther 2:21 and 6:2 and the temple guard of 2 Kings 23:11 (NetanMelek) were probably not eunuchs either.

- 2 Kings 25:19 and Jeremiah 52:25 provide a summary of officials and officers kidnapped from Jerusalem and executed by the Babylonians. The head of the warriors, described in the original sources as saris, is called a eunuch by the $K J V$, but an officer by the NAV and the NIV. The word saris also occurs in the descriptions of the entourages of the kings Joachin (2 Kings 24:12) and Sedicias (Jer. 29:2), but these were probably not eunuchs. In a later revolt against Babylon (Jer. 41:16), the original sources mention that the inhabitants of Masphath included sarisim. The $K J V$ refers to them as eunuchs, but in the NAV and the NIV they are merely called officials. 
- The two prophetic texts of Samuel (1 Sam. 8:15) and Jeremiah (Jer. 34:19) probably refer to officials, although the $K J V$ translates saris in the latter case as eunuch.

- In Daniel 2:48, Daniel is promoted to the rank of governor and chief of the royal advisers, in terms of the word saris. There is no reason to think that he was made a eunuch. In Daniel 11:18, one of his prophecies refers to an important ruler as saris, but the word is probably not intended to mean eunuch here either.

Because Nehemiah is called an oinochoos in the Septuagint version of Nehemiah 1:11, he has been considered by some to be a eunuch. However, this Greek word, which could easily be confused with eunouchos, means cup-bearer (literally, "pourer"). In the Vulgate, Nehemiah is called a pincerna (with the same meaning) (Sheriffs 1990:356).

\subsubsection{Textual context inconclusive}

- In 2 Kings 9:32, we are told of the victorious Jehu riding into Samaria and being taunted by the queen mother, Jezebel, from an elevated window in the palace. When Jehu demands that she be thrown out of the window, two or three people (described in the original texts as sarisim) respond. Both the KJV and the NIV translate this as "eunuchs", while the NAV calls them merely "palace officials". The context of the story suggests that they were employed in the women's section of the palace, which strengthens the possibility that they may have been eunuchs. Hoever, in Israelite communities, unlike those of the Assyrians and Babylonians, eunuchs were rare (Gray 1974:580-3).

- 2 Kings 18:17 tells that the Assyrian king was accompanied by his army, senior officers and officials: here the NAV and the NIV translate saris as chief officials and commanders, while the $K J V$ (as well as the 1933 Afrikaans Bible translation) specify that they are, among others, rabshakeh and rabsaris. In Jeremiah 39:3, 13 the Babylonian chief officials and officer corps are described. Again in the KJV and the 1933 Afrikaans Bible there is mention of a rabsaris (Nabusezban), who is called a "chief officer" in the NIV. Given the Assyrian custom of appointing eunuchs to senior administrative and military posts, many of the officials mentioned may well have been eunuchs. 
- In Jeremiah 38:7-13 we have the story of Ebed-Melek, a Cussite official in the court of Sedecias, who persuades the king to release Jeremiah from his captivity in a pit in the palace. The $N A V$ and the KJV refer to him as a "eunuch", while the NIV calls him an "official", adding a footnote to the effect that he could have been a eunuch. The fact that he, as a foreigner, held an important office, could be related to the popular Middle Eastern custom of castrating prisoners of war or slaves before employing them (Juynboll 1974:584-5).

- Daniel 1:3,4 and 8-15 refer to court officials (Asphenez, among others) who had to look after Daniel and other young exiles. According to the $K J V$, Asphenez was the chief of the eunuchs, while the NAV and the NIV call him simply a chief palace official. Again, according to Babylonian custom, there were probably many eunuchs in the service of the palace, not only those guarding the women. This text provides little supporting evidence, but both the Septuagint and the Vulgate refer to the officials as leaders among the eunuchs (archi-eunouchos and praepositus eunuchorum, respectively). The suggestion that Daniel himself was a eunuch (Josephus Ant. 10.186) is unlikely in the light of Daniel 1:4, since young Hebrews intended for service in the palace had to be free of any physical defect.

\subsection{The New Testament}

Only two scriptural passages in the New Testament refer to eunuchs (eunouchos), namely Matthew 19:12 and Acts 8:27-39. It has already been shown that eunouchos, like saris in the Old Testament, had more than one meaning, and could also mean "official".

- In Matthew 19:12, Christ describes three types of people as unfit for marriage, namely those who have been castrated (which all exegetes take as indicating eunuchs); those born incapable (congenital eunuchs) and those who, by their own free choice and for the glory of God's Kingdom, abstain from marrying (voluntary celibates).

- Acts 8:27-39 tells the story of the conversion of an Ethiopian court official by the apostle Philip. The NAV, the KJB and the NIV all 
call him a eunuch, but the word eunouchos may be meant in the sense of official. As the sole representative of the Ethiopian monarch in Palestine, he was obviously a very senior official, and there is no pressing reason to believe that he was also a eunuch (Louw et al. 1993, vol. 1:107, 479, esp. n. 7, 482; vol. 2: 67, 109). However, in his comprehensive theological discussion of this episode, which is one of the best-known references to eunuchs in the Bible, Spencer (1993:155-65) does indeed take the official to be a eunuch, and finds his study of Isaiah 53 particularly significant.

\section{DISCUSSION}

\subsection{Assessing saris and eunouchos}

Approximately 50 passages in the Bible, representing 28 identifiable incidents, may involve human castration. All the Old Testament references are linked to the Biblical Hebrew word saris except for Deuteronomy 23:1, where the process of castration is described without the use of the word, and Leviticus 22:24, where animal castration by crushing (Hebrew katut) the sexual organs is indicated. The New Testament contains two references to eunuchs (Greek eunouchos).

In the Septuagint, saris is consistently translated as eunouchos, except for the use of spadon in Genesis 37:36 (referring to Potiphar) and Isaiah 39:7 (referring to the castration of princes), archi-eunouchos in Daniel 1:3, 7, 8-15 and 18 (referring to the head eunuch), and archon in Daniel 2:48 (referring to Daniel as the governor). In Jeremiah 38: 7, Ebed-Melek's rank is given as "he who was in the house of the king".

In the Vulgate, saris is translated by the Latin eunuchus, except in Esther 2:3 (where Hegai is described as a minister), Daniel 1:3, 7, 815, and 18 (praepositus eunuchorum) and Daniel 2:48 (Daniel's appointment as praefectus magistratuum).

Nehemiah (Neh. 1:11) is described as oinochoos in the Septuagint and as pincerna in the Vulgate, meaning cup-bearer or butler (literally, "pourer"). His inclusion in a list of possible references to eunuchs may derive from misinterpretation of the word oinochoos (Sheriffs 1990:356).

We accept that the Law of Moses in Deuteronomy 23:1 and the prophecy of Isaiah 56:3-5 refer to genuine eunuchdom. We also con- 
sider saris in Esther 1 and Isaiah's prophecy in 2 Kings 10:18 and Isaiah 39:7 to refer to eunuchs or castration. Matthew 19:12 discusses forms of eunuchdom while Leviticus 22:24 deals with the castration of animals.

The following passages may refer to eunuchs, but the possibility that saris merely indicates officials can not be excluded: 2 Kings 9:32 (staff in Jezebel's palace), 2 Kings 18:17 and Jeremiah 39:3, 13 (senior officials in the Assyrian and Babylonian armies), 2 Kings 18: 17 and Jeremiah 38:7-13 (the Cussite, Ebed-Melek) and Daniel 1:3, 7, 8-15 and 18 (Asphenez and other highly ranked officials). Whether the Ethiopian courtier (Acts 8:27-39) was a eunuch must remain in the realm of speculation.

In the remaining passages discussed, we are of the opinion that saris refers to the rank of official or commander.

\subsection{Concepts related to eunuchdom}

In Matthew 19:12 three classes of people unable to marry are mentioned, namely those who have been unfit to do so since childhood (congenital eunuchs), those who have become unfit through disablement by human hands (eunuchs) and those who have voluntarily chosen, to the glory of the Kingdom of God, to abstain from marriage. Castration and eunuchdom as a result have already been fully discussed.

The concept of congenital eunuchs (saris hamma) refers to a condition in which the subject has not been castrated, but never develops normal sexual powers or desires, and is sterile. Modern science recognises a group of syndromes caused by faulty descent or early disease of the testes, or by congenital defects in the sexual organs (particularly the testes). Sterility, impotence, and typical "eunuchoid" body types develop, but without any mental incapacitation (Plymate \& Paulsen 1990:948-61). These conditions are very rare, and must also have been scarce in antiquity, in comparison with eunuchism due to castration. Hermaphroditism (genuine bisexuality) is also extremely rare, while apparent hermaphroditism due to diseases of the endocrine (hormonesecreting) glands is slightly more common but usually accompanied by early death. Men who eschew heterosexual marriage due to homosexual inclinations are, of course, physically normal, without eunuchoid aberrations, but may have been included in the group mentioned in 
Matthew 19:12. However, a contemporary writer such as the Latin author, Juvenal, distinguishes clearly in his satires between homosexual men and eunuchs. Due to the rarity of the category, one is surprised that the evangelist gave such prominence to congenital eunuchs. He may perhaps have been familiar with a role model of this very rare condition, or have included homosexuality in the group. The Hebrew use of saris hamma (congenital eunuch) as opposed to saris adam (acquired eunuchism) nevertheless indicates that both conditions were recognised.

Although not a form of eunuchism in terms of the definition above, asceticism and voluntary abstention from sexual activity played a strong role among the early Fathers of the Christian Church, giving rise in due course to the establishment of the monastic religious orders (Sanders 1972:1026-7; Horstmanshoff 2000:105-14). A relationship was perceived between eunuchism and voluntary abstention from sexual activity (celibacy) as a pure and total dedication to God. Faulty interpretation of Matthew 19:12 even led a revered Father of the early Church, Origen, to castrate himself — an act which, in retrospect and with greater insight, he bitterly regretted. Clement of Alexandria $\left(1^{\text {st }}\right.$ century AD) recommended the virtues of asceticism (engkrateia), but warned that celibacy was worthless unless undertaken in the love of Christ. Nevertheless, various fanatical Christian sects, such as the Arabian Valesians, the Manicheans and the Phrygian Montanists, accepted self-castration as part of their religious practice. Church leaders such as Cassian and Tatian even denounced sexual intercourse as diabolical, but the Council of Nicaea (325 AD) strongly condemned castration (Sanders 1972:1026-8).

\section{CONCLUSION}

Eunuchism always played a minor role in Israelite-Jewish communities in comparison with Middle Eastern societies such as the Assyrians, the Babylonians and the Persians, among whom human castration probably originated in the $2^{\text {nd }}$ millennium BC and in which eunuchs formed an accepted class (as in the later Greek and Roman civilisations). The Law of Moses exiled eunuchs from the people of Israel, and even forbade the sacrifice of castrated animals. Later, probably in the $6^{\text {th }}$ and $5^{\text {th }}$ centuries BC, Isaiah urges eunuchs not to see themselves as permanently excluded from the circle of faith. The Bible provides 
evidence that eunuchs played a limited role in the community and history of Israel. As has been indicated above, most of the references to eunuchs in the Bible can in fact be traced to practices common among Egyptians, Persians, or other Mesopotamian peoples, in particular. The early Christian Church apparently did not reject eunuchs, but forbade castration. A connection was perceived to exist between eunuchism, abstention from sexual practices, and celibacy as a pure and total dedication to God (Horstmanshoff 2000:112). Due to misinterpretation of Biblical texts, Matthew 19:12 in particular, this led to a brief flowering of fanatical church cults practising castration, but ultimately resulted in the establishment of permanent monastic religious orders based on celibacy.

\section{REFERENCES}

\section{GRAY J}

1970. I and II Kings. A commentary. London: SCM Press. Old Testament Library.

\section{GRAY L H}

1974. Eunuch. In: J. Hastings (ed.), Encyclopaedia of religion and ethics. Vol. 5. Edinburgh: T. \& T. Clark.

\section{HORSTMANSHOFF M}

2000. Who is the true eunuch? Medical and religious ideas about eunuchs and castration in the works of Clement of Alexandria. In: S. Kottek \& M. Horstmanshoff (eds.), From Athens to Jerusalem. Rotterdam: Erasmus Publishing.

Hug A A

1918. Eunuchen. In: E. Kroll et al. (eds.), Paulys Realencyclopädie der classischen Altertumswissenschaft. Suppl. Band 3. Stuttgart: Metzler'sche Verlagsbuchhandlung.

JASTROW M 1950. A dictionary of the Targumim, the Thalmud Babli and Yerushalmi and the Midrashic literature. New York: Pardes Publishing House.

JUVENAL

1967. The sixteen satires (Transl. by P. Green). London: Penguin. Penguin Classics. 


\section{Eunuchs in the Bible}

\section{JUYNBOLL T W}

1974. Eunuch (Muslim). In: J. Hastings (ed.), Encyclopaedia of religion and etbics.

Vol. 5. Edinburgh: T. \& T. Clark.

\section{LEVINSON J}

2000. Cultural androgyny in Rabbinic literature. In: S. Kottek \& M. Horstmanshoff (eds.), From Athens to Jerusalem. Rotterdam: Erasmus Publishing.

LiDDELL H G, SCOTT R \& JONES H S 1968 (1843). A Greek-English lexicon. Oxford: Clarendon Press.

Louw J P, Nida E A, SMith R B \& Muson K A 1993 (1988). Greek-English lexicon of the New Testament based on semantic domains. Goodwood, Cape: Bible Society of South Africa.

\section{KOEHLER I \& BAUMGARTEN W}

1958. Lexicon in Veteris Testamenti Libros. Leiden: E. J. Brill.

\section{Malina B J \& Neyrey J H}

1991. Conflict in Luke-Acts: labelling and deviance theory. In: J.H. Neyrey (ed.), The social world of Luke-Acts: models for interpretation. Hendrickson Publishers.

\section{MANDELKERN S}

1975. Veteris Testamenti Concordantiae Hebraicae atque Chaldaicae. Graz: Akademische Druck u. Verlagsanstalt.

Plymate S R \& Paulsen C A

1990. Male hypogonadism. In: K.L. Becker (ed.), Principles and practice of endocrinology and metabolism. Philadelphia: J. B. Lippincor Co.

\section{SANDERS G M}

1972. Gallos. In: T. Klauser (ed.), Reallexikon für Antike und Christentum. Vol. 5. Stuttgart: Hierseman.

SHERIFFs R J A 1990. Eunuch. In: J.D. Douglas et al. (eds.), New Bible Dictionary. $2^{\text {nd }}$ Edition. Leicester: Intervarsity Press.

\section{SPENCER F S}

1993. The Ethiopian eunuch and his Bible: a social science analysis. Biblical Theology Bulletin 22:155-165. 